Research Article

\title{
A cross-sectional comparative study to determine the factors contributing to the academic performance of the high performers and low performers in 2nd year medical students
}

\author{
Yogeeta Sushant Walke*, Lois James Samuel, Laveena Vassant Bandodkar
}

\begin{abstract}
Department of Pharmacology, Goa Medical College, Bambolim, Goa, India
\end{abstract}

Received: 22 July 2015

Revised: 10 September 2015

Accepted: 11 September 2015

\section{*Correspondence to:}

Dr. Yogeeta Sushant Walke, Email: cdcsushant@hotmail. com

Copyright: (C) the author(s), publisher and licensee Medip Academy. This is an openaccess article distributed under the terms of the Creative Commons Attribution NonCommercial License, which permits unrestricted noncommercial use, distribution, and reproduction in any medium, provided the original work is properly cited.

\begin{abstract}
Background: MBBS course content is extensive and requires immense and strenuous effort on the part of the medical students to complete it. Some students excel in their academics while others strive to pass and some even drop out. If the factors contributing to the excellent academic performance could be identified, these factors then can be incorporated to upgrade the struggling medical students. Hence, early identification of low achievers and the factors responsible for their poor performance is crucial. We undertook this study to identify the various factors influencing the academic performance of these two groups of students.

Methods: We identified the top thirty percentile and bottom 30 percentile students in the subject of pharmacology based on their third semester examination marks. All the 62 students opted to participate in the study, and their informed consent was taken. They were then given the questionnaire and allowed to answer in a stress free atmosphere.

Results: Factors which were statistically significant in contributing to the good performance of high achievers were the use of reference books from the library, learning from other sources such as patients, avoiding repetition of mistakes made in the past, proper time management skills, and having immense intrinsic motivation to study.

Conclusion: Through our study, we identified important factors contributing to high performance in academics, and we concluded that students should incorporate all the factors in a well-coordinated manner rather than focusing on any single factor. If executed, appropriately it will definitely upgrade their academic performance and prevent undesirable failures.
\end{abstract}

Keywords: High achievers, Low achievers, Academic performance, Learning strategies

\section{INTRODUCTION}

Medical colleges follow stringent selection procedures for admission of medical students to ensure a high academic standard. It is the process undertaken to eliminate those who would be unable to meet the vigorous academic requirement. ${ }^{1}$ During their medical undergraduate course some students excel in their academics, many strive to pass the medical course while few even drop out. ${ }^{2,3}$

If the factors contributing to the excellent academic performance are identified, these factors can be incorporated to upgrade the struggling medical students. Past studies have shown that there are several factors such as motivation, emotion, exam results, physical and emotional well-being that are responsible for their academic success. ${ }^{4,5}$ Good exam results positively reinforce their academic performance while poor results coupled with anxiety and boredom can adversely influence them. ${ }^{6,7}$ Personal abilities such as creativity, self-confidence, and concentration were important factors highlighted by the medical students to achieve success. A systematic review of literature in Nottingham showed that eight subscales had emerged consistently as predictors of success in medical training: Dominance, tolerance, sociability, self-acceptance, wellbeing, responsibility, "achievement via conformance and achievement via independence." ${ }^{8}$ According to Stegers-Jeger et al., intrinsic motivation, scheduled learning activities, and innovative learning strategies facilitate the learning process and help them to perform well in the exams. ${ }^{2}$ 
Medical students are known to be very talented and highly motivated, but there are some who succumb to the excessive pressures and set a challenge to the educators. Such students require more attention and special help from the faculty. The issue of failures and drop out cannot be left unaddressed as it is associated with many unfavorable consequences. ${ }^{9}$ First, the student may suffer substantial personal or financial hardship as a result of exam failures. Second, there is a burden on the faculty and the university, with unnecessary time spent on meeting and advising the struggling students and setting additional exams. Third, there is societal loss when a sponsored student drops out. ${ }^{10}$

Hence, early identification of low achievers and the factors responsible for their poor performance is important to implement interventional programs in the medical curriculum. Thus, we undertook this study to identify the various factors influencing the academic performance of the high achievers as well as the low achievers.

\section{METHODS}

We identified thirty top percentile and bottom thirty percentile students in the subject of pharmacology based on their third semester terminal marks. There were 31 students in each group. These students were invited to participate in the study. The study protocol was explained to them in detail. All 62 students opted to participate in the study, and their informed consent was taken. They were then given the questionnaire and allowed to answer in the stress free atmosphere (Appendix 1). They were given adequate time to answer the questionnaire.

\section{Ethical aspects}

Approval for conducting the study was obtained from the Institutional Ethical Committee of the Goa Medical College, Bambolim Goa.

\section{Collection of data}

The completed questionnaire were collected from all 62 students.

They were allowed to respond in their own time and privacy was ensured. The participation was entirely voluntary.

\section{RESULTS}

Following are the results in tabulated form obtained after analyzing the feedback form.

Table 1 shows $55 \%$ of good performers used mind maps to aid their studies, whereas only $29 \%$ of poor performers used mind maps.
Table 2 shows $100 \%$ of good performers made use of library facilities to aid their studies, whereas only $81 \%$ of poor performers made use of library facilities.

Table 3 shows 97\% of good performers learned from other sources as well, whereas only $61 \%$ of poor performers learned from other sources.

Table 4 shows good performers had 100\% attendance, whereas poor performers had only $87 \%$ of attendance

Table 5 shows $90 \%$ of good performers preferred self-study, whereas only $74 \%$ of poor performers preferred self-study.

Table 6 shows $52 \%$ of good performers revised weekly, whereas only $45 \%$ of poor performers revised weekly.

Table 7 shows $65 \%$ of good performers felt that they had good short-term memory, whereas only $42 \%$ of poor performers felt so.

Table 8 shows $52 \%$ of good performers felt that they had average long-term memory, whereas only $45 \%$ of poor performers felt so.

Table 9 shows $97 \%$ of good performers were motivated to study, whereas only $84 \%$ of poor performers were motivated to study.

Table 10 shows $45 \%$ of good performers were home sick, whereas $19 \%$ of poor performers were home sick.

\section{DISCUSSION}

Although the academics in the medical field is challenging, some students perform extremely well while others struggle. A challenge for medical educators is to identify factors that lead to student success in medical school and beyond. ${ }^{11}$ Through our study, we have made an effort to identify various factors contributing to their academic performance.

To keep at par with the academic schedule, it is necessary to study and to prepare notes regularly, but in our study we did not find any significant difference between the two groups.

$34 \%$ of the good performers studied for $>2$ hrs per day, whereas only $16 \%$ of poor performers studied for $2-4 \mathrm{hrs}$.

Good performers, as well as poor performers appropriately, used their holidays for academic gains. Most students preferred self-study irrespective of the group which they belonged to. Self-study followed by discussion with friend or group would have enhanced their academic performance. Good performers revised their academic subject either weekly or monthly depending on the availability of time. Regular revision of topic helps to remember the subject better. Students from both the group referred to previous 
Table 1: Comparison of learning strategies.

\begin{tabular}{|c|c|c|c|c|c|c|c|}
\hline \multirow[t]{2}{*}{$\begin{array}{l}\text { Learning } \\
\text { strategy }\end{array}$} & \multicolumn{2}{|c|}{$\begin{array}{l}\text { Good performers } \\
\qquad(\mathrm{n}=\mathbf{3 1})(\%)\end{array}$} & \multicolumn{2}{|c|}{$\begin{array}{l}\text { Poor performers } \\
\qquad(\mathrm{n}=\mathbf{3 1})(\%)\end{array}$} & \multirow[t]{2}{*}{ Chi-square } & \multirow[t]{2}{*}{ df } & \multirow[t]{2}{*}{ p value } \\
\hline & Yes & No & Yes & No & & & \\
\hline Regular study & $10(32)$ & $21(68)$ & $4(13)$ & $27(87)$ & 30 & 1 & 0.128 \\
\hline Regularly prepares notes & $9(29)$ & $22(71)$ & $7(23)$ & $24(77)$ & 0.842 & 1 & 0.7716 \\
\hline Referred to previous question papers & $22(71)$ & $9(29)$ & $21(68)$ & $10(32)$ & 0 & 1 & 1.000 \\
\hline Mind map & $17(55)$ & $14(45)$ & $9(29)$ & $22(71)$ & 3.24 & 1 & 0.0716 \\
\hline Mnemonics & $17(55)$ & $14(45)$ & $19(61)$ & $12(39)$ & 0.0662 & 1 & 0.7969 \\
\hline Guidance from faculty or senior students & $20(65)$ & $11(35)$ & $17(55)$ & $14(45)$ & 0.2681 & 1 & 0.6046 \\
\hline Library & $31(100)$ & 0 & $25(81)$ & $6(19)$ & 4.613 & 1 & 0.0317 \\
\hline Learn from other sources & $30(97)$ & $1(3)$ & $19(61)$ & $12(39)$ & 9.73 & 1 & 0.0018 \\
\hline Attendance & $31(100)$ & 0 & $27(87)$ & $4(13)$ & 2.405 & 1 & 0.1209 \\
\hline
\end{tabular}

Table 2: Comparison of learning strategy - minimum hours of study.

\begin{tabular}{|c|c|c|c|c|c|c|c|c|c|}
\hline \multirow{2}{*}{$\begin{array}{l}\text { Learning } \\
\text { strategy }\end{array}$} & \multicolumn{3}{|c|}{ Good performance (\%) } & \multicolumn{3}{|c|}{ Poor performers $(\%)$} & \multirow[t]{2}{*}{ Chi-square } & \multirow[t]{2}{*}{ df } & \multirow[t]{2}{*}{ p value } \\
\hline & $<2 \mathrm{hrs}$ & 2-4 hrs & $4 \mathrm{hrs}$ & $<2 \mathrm{hrs}$ & 2-4 hrs & $>4 \mathrm{hrs}$ & & & \\
\hline Minimum hrs of study & $20(66)$ & $9(29)$ & $2(5)$ & $26(84)$ & $5(16)$ & 0 & 3.92 & 2 & 0.14 \\
\hline Study during holidays & $10(320$ & $10(32)$ & $11(36)$ & $16(52)$ & $5(16)$ & $10(32)$ & 3.0989 & 2 & 0.21 \\
\hline
\end{tabular}

Table 3: Comparison of learning strategy - mode of study.

\begin{tabular}{|c|c|c|c|c|c|c|c|c|c|}
\hline \multirow{2}{*}{$\begin{array}{l}\text { Learning } \\
\text { strategy }\end{array}$} & \multicolumn{3}{|c|}{ Good performance (\%) } & \multicolumn{3}{|c|}{ Poor performers (\%) } & \multirow[t]{2}{*}{ Chi-square } & \multirow[t]{2}{*}{ df } & \multirow[t]{2}{*}{ p value } \\
\hline & $\begin{array}{l}\text { Self- } \\
\text { study }\end{array}$ & $\begin{array}{l}\text { Study with } \\
\text { friend }\end{array}$ & $\begin{array}{l}\text { Study in } \\
\text { a group }\end{array}$ & $\begin{array}{l}\text { Self- } \\
\text { study }\end{array}$ & $\begin{array}{l}\text { Study with } \\
\text { friend }\end{array}$ & $\begin{array}{l}\text { Study in } \\
\text { a group }\end{array}$ & & & \\
\hline $\begin{array}{l}\text { Preferred } \\
\text { mode of study }\end{array}$ & $28(90)$ & $3(10)$ & 0 & $23(74)$ & $6(19)$ & $2(7)$ & 3.4902 & 2 & 0.17 \\
\hline
\end{tabular}

Table 4: Comparison of learning strategy - revision of topics.

\begin{tabular}{|c|c|c|c|c|c|c|c|c|c|}
\hline \multirow{2}{*}{$\begin{array}{l}\text { Learning } \\
\text { strategy }\end{array}$} & \multicolumn{3}{|c|}{ Good performance (\%) } & \multicolumn{3}{|c|}{ Poor performers $(\%)$} & \multirow[t]{2}{*}{ Chi-square } & \multirow[t]{2}{*}{ df } & \multirow[t]{2}{*}{ p value } \\
\hline & Daily & Weekly & Monthly & Daily & Weekly & Monthly & & & \\
\hline Revise the topics & $1(3)$ & $16(52)$ & $14(45)$ & 0 & $14(45)$ & $17(55)$ & 1.42 & 2 & 0.49 \\
\hline
\end{tabular}

Table 5: Comparison of learning strategy - memory.

\begin{tabular}{|c|c|c|c|c|c|c|c|c|c|}
\hline \multirow{2}{*}{$\begin{array}{l}\text { Learning } \\
\text { strategy }\end{array}$} & \multicolumn{3}{|c|}{ Good performance (\%) } & \multicolumn{3}{|c|}{ Poor performers $(\%)$} & \multirow[t]{2}{*}{ Chi-square } & \multirow[t]{2}{*}{ df } & \multirow[t]{2}{*}{ p value } \\
\hline & Average & Good & Excellent & Average & Good & Excellent & & & \\
\hline Short-term memory & $8(25)$ & $20(65)$ & $3(10)$ & $15(48)$ & $13(42)$ & $3(10)$ & 3.615 & 2 & 0.16 \\
\hline Long-term memory & $16(52)$ & $13(42)$ & $2(6)$ & $14(45)$ & $13(42)$ & $4(13)$ & 13.572 & 2 & 0.0011 \\
\hline
\end{tabular}

Table 6: Comparison of resource management - time of study.

\begin{tabular}{|lccccccc|}
\hline $\begin{array}{l}\text { Resource } \\
\text { management }\end{array}$ & $\begin{array}{c}\text { Good performers }(\mathbf{n = 3 1})(\%) \\
\text { Early } \\
\text { morning }\end{array}$ & $\begin{array}{c}\text { Poor performers }(\mathbf{n}=\mathbf{3 1})(\%) \\
\text { late at night }\end{array}$ & $\begin{array}{c}\text { Chi-square } \\
\text { Early } \\
\text { morning }\end{array}$ & $\begin{array}{c}\text { Evening and } \\
\text { late at night }\end{array}$ & df & p value \\
\hline Time of study & $10(32)$ & $21(68)$ & $8(26)$ & $23(74)$ & 0.0783 & 1 & 0.77 \\
\hline
\end{tabular}

examination question papers, and there was no statistical difference between them.

One of the important factors among the good performers was use of mind map as a learning aid. The mind map is a visual depiction of an idea or a topic in a well-coordinated and categorized manner. The brain finds mind map fascinating, hence easy to grasp and assimilate. ${ }^{12}$ The mind map enables student to understand the comprehensive matter at a glance. $55 \%$ of the Good performers used the mind map as a learning 
Table 7: Comparison of resource management - others.

\begin{tabular}{|c|c|c|c|c|c|c|c|c|c|}
\hline \multirow[t]{2}{*}{ Resource management } & \multicolumn{3}{|c|}{ Good performance (\%) } & \multicolumn{3}{|c|}{ Poor performers (\%) } & \multirow[t]{2}{*}{ Chi-square } & \multirow[t]{2}{*}{ df } & \multirow[t]{2}{*}{ p value } \\
\hline & $<2$ hrs & 2-4 hrs & $4 \mathrm{hrs}$ & $<2 \mathrm{hrs}$ & 2-4 hrs & $>4 \mathrm{hrs}$ & & & \\
\hline $\begin{array}{l}\text { Time spent on watching } \\
\text { television, internet, etc. }\end{array}$ & $23(74)$ & $8(26)$ & 0 & $21(68)$ & $7(23)$ & $3(9)$ & 3.157 & 2 & 0.2062 \\
\hline Time spent on travelling & $21(98)$ & $10(32)$ & 0 & $21(68)$ & $7(23)$ & $3(9)$ & 3.529 & 2 & 0.1712 \\
\hline $\begin{array}{l}\text { Time spent on social } \\
\text { function }\end{array}$ & $12(38)$ & $3(10)$ & $5(16)$ & $20(65)$ & $6(19)$ & $5(16)$ & 1.209 & 2 & 0.5463 \\
\hline
\end{tabular}

Table 8: Comparison of motivation to study.

\begin{tabular}{|c|c|c|c|c|c|c|c|}
\hline \multirow[t]{2}{*}{ Motivation } & \multicolumn{2}{|c|}{ Good performers $(n=31)(\%)$} & \multicolumn{2}{|c|}{ Poor performers $(n=31)(\%)$} & \multirow[t]{2}{*}{ Chi-square } & \multirow[t]{2}{*}{ df } & \multirow[t]{2}{*}{ p value } \\
\hline & Yes & No & Yes & No & & & \\
\hline Motivated to study & $30(97)$ & $1(3)$ & $26(84)$ & $5(16)$ & 1.6607 & 1 & 0.1975 \\
\hline
\end{tabular}

Table 9: Comparison of dealing with non-academics - duration of sleep.

\begin{tabular}{|c|c|c|c|c|c|c|c|c|c|}
\hline \multirow[t]{2}{*}{ Dealing with non-academics } & \multicolumn{3}{|c|}{$\begin{array}{l}\text { Good performers } \\
\quad(n=31)(\%)\end{array}$} & \multicolumn{3}{|c|}{$\begin{array}{l}\text { Poor performers } \\
\quad(n=31)(\%)\end{array}$} & \multirow[t]{2}{*}{ Chi-square } & \multirow[t]{2}{*}{ df } & \multirow[t]{2}{*}{ p value } \\
\hline & $<2$ hrs & 2-4 hrs & $>4 \mathrm{hrs}$ & $<2$ hrs & 2-4 hrs & $>4$ hrs & & & \\
\hline Duration of sleep before exams & $1(3)$ & $8(26)$ & $22(71)$ & $1(3)$ & $16(52)$ & $14(45)$ & 4.44 & 2 & 0.108 \\
\hline
\end{tabular}

Table 10: Comparison of dealing with non-academics - others.

\begin{tabular}{|c|c|c|c|c|c|c|c|}
\hline \multirow{2}{*}{$\begin{array}{l}\text { Dealing with } \\
\text { non-academics }\end{array}$} & \multicolumn{2}{|c|}{ Good performers $(n=31)(\%)$} & \multicolumn{2}{|c|}{ Poor performers $(n=31)(\%)$} & \multirow[t]{2}{*}{ Chi-square } & \multirow[t]{2}{*}{ df } & \multirow[t]{2}{*}{ p value } \\
\hline & Yes & No & Yes & No & & & \\
\hline Language barrier & $2(6)$ & $29(94)$ & $3(10)$ & $28(90)$ & 0 & 1 & 1.000 \\
\hline Home sick & $14(45)$ & $17(55)$ & $6(19)$ & $25(81)$ & 3.6167 & 1 & 0.0572 \\
\hline
\end{tabular}

df: Degree of freedom, n: Number of students

aid while only $29 \%$ of poor performers used mind map, but this difference was statistically not significant. According to Solso, mnemonics are techniques or devices, either verbal or visual in nature which facilitates to improve the storage and recall of new information. ${ }^{13}$ Mnemonics have been proven to be extremely effective in improving memory. ${ }^{14,15}$ In mnemonic strategies, previously learnt information is correlated with the new information to facilitate storage and recall. ${ }^{16}$ According to Thompson when new information is integrated into the existing cognitive units, it enables the learner to achieve quicker learning by providing retrieval cues. ${ }^{17} 55 \%$ of good performers made use of mnemonics for their studies, whereas $61 \%$ of poor performers used mnemonics for their studies. Though a higher number of poor performers made use of mnemonics, they neither studied systematically nor revised the topics regularly, so the advantage of using mnemonics was lost. Students who performed better either received guidance from faculty or senior students. Since the portion is vast, student may not be able to comprehend the topic and hence a regular guidance from faculty or senior students may go a long way to improving their academic performance.

In our study, $100 \%$ of the good performers availed the library facility while only $81 \%$ of the poor performers did so. The difference between the two groups was statistically significant. This is in coherence with the study conducted by Wong and Webb, who found a positive correlation between the use of library and achievement of higher grades. ${ }^{18}$ Good performers also learnt from other sources such as patients. Clinical topics cannot be learned only by studying lecture notes and books. It has to be integrated with clinical knowledge. This integration helped them to understand and remember the topic better. Good performers also learnt from their past mistakes. Failure was not a deterrent, but a motivator to improve their academic performance.

Regular lecture attendance improves academic performance. ${ }^{19}$ Chan et al., Rodgers, Kirby and McElroy, and Dolton et al. found a positive and significant relationship between class attendance and academic performance. ${ }^{20-23}$

Regular attendance to course lectures and early revision were found to be important factors for improvement of student's performance. ${ }^{24,25}$ In our study, we did not find any statistically significant difference between the two groups. We did not find any correlation between performance and attendance. The majority of the students in both the group regularly attended lectures. This could be due to university 
rule of minimum $75 \%$ attendance to qualify to answer the final examinations.

Good performers felt that they had good long term memory. There was a statistically significant difference between the two groups as far as their impression about their own long term memory was concerned; many high performers felt that they were blessed with good long-term memory. Academic success requires effective time management skills. ${ }^{26}$ Students who do not utilize their time efficiently are unable to master the content. Therefore, the onus lies on the faculty to provide the assistance and support in time management. This will enable them to utilize their study time more efficiently and effectively which ultimately will improve their academic performance. ${ }^{27}$ According to Artino et al., intrinsic motivation and self-efficacy play a pivotal role in achieving academic goals. ${ }^{6}$ Homesickness and language barriers negatively influence students' academic achievements. ${ }^{28,29}$ Salamonson et al., conducted a study among 1st year nursing students; they noticed a direct correlation between low English test scores and low academic grades among students with English as second language. ${ }^{27}$

According to our study, factors which were statistically significant in contributing to good performance of high achievers were reference books from the library, learning from other sources such as patients and avoidance of repetition of mistakes made in the past, proper time management skills and having immense intrinsic motivation to study.

\section{CONCLUSION}

Our study revealed that some poor performers in spite of their sincere effort to study were unable to achieve good results. The reason could be their inability to coordinate all the contributing factors appropriately. Some were unaware of the use of mind maps while some others did not avail of the library facility also some others were lacking in their time management skills and intrinsic motivation.

\section{Funding: No funding sources}

Conflict of interest: None declared

Ethical approval: The study was approved by the Institutional Ethics Committee

\section{REFERENCES}

1. Lumsden MA, Bore M, Millar K, Jack R, Powis D. Assessment of personal qualities in relation to admission to medical school. Med Educ. 2005;39(3):258-65.

2. Stegers-Jager KM, Cohen-Schotanus J, Themmen AP. Motivation, learning strategies, participation and medical school performance. Med Educ. 2012;46(7):678-88.

3. Arulampalam W, Naylor R, Smith J. Factors affecting the probability of first year medical student dropout in the UK: a logistic analysis for the intake cohorts of 1980-92. Med Educ. 2004;38(5):492-503.
4. McManus IC, Smithers E, Partridge P, Keeling A, Fleming PR. A levels and intelligence as predictors of medical careers in UK doctors: 20 year prospective study. BMJ. 2003;327(407):139-42.

5. Kilminster S, Cottrell D, Grant J, Jolly B. AMEE Guide No. 27: effective educational and clinical supervision. Med Teach. 2007;29(1):2-19.

6. Artino AR, La Rochelle JS, Durning SJ. Second-year medical students' motivational beliefs, emotions, and achievement. Med Educ. 2010;44(12):1203-12.

7. Abdulghani HM, Alrowais NA, Bin-Saad NS, Al-Subaie NM, Haji AM, Alhaqwi AI. Sleep disorder among medical students: relationship to their academic performance. Med Teach. 2012;34 Suppl 1:S37-41.

8. Ferguson E, James D, Madeley L. Factors associated with success in medical school: systematic review of the literature. BMJ. 2002;324(7343):952-7.

9. Stegers-Jager KM. At-Risk Medical Students Characteristics and Possible Interventions. Thesis. The Netherlands: Erasmus University Rotterdam; 2012.

10. Walke YS, Samuel LJ. Cross sectional comparative study to assess the level of stress and its effect on attendance and performance among second year medical students. Int J Med Appl Sci. 2015;4 Suppl 1:221-8.

11. Ericsson KA Deliberate practice and acquisition of expert performance: a general overview. Acad Emerg Med. 2008;15(11):988-94.

12. Busan T, Busan B. The Mind Map Book: how to Use Radiant Thinking to Maximize Your Brains Untapped Potential? New York: Penguin Books USA Inc.; 1994.

13. Solso RL. Cognitive Psychology. 4th Edition. Boston: Allyn and Bacon; 1995.

14. Mastropieri MA, Scruggs TE. Mnemonic social studies instruction: classroom applications. Remedial Spec Educ. 1989;10(3):40-6.

15. Bulgren JA, Schumaker JB, Deshler DD. The effects of a recall enhancement routine on the test performance of secondary students with and without learning disabilities. Learn Disabil Res Pract. 1994;9:2-11.

16. Abdulghani HM, Al-Drees AA, Khalil MS, Ahmad F, Ponnamperuma GG, Amin Z. What factors determine academic achievement in high achieving undergraduate medical students? A qualitative study. Med Teach. 2014;36 Suppl 1:S43-8.

17. Thompson I. Memory in language learning. In: Wenden A, Rubin J, editors. Learner Strategies in Language Learning. Volume 8. New York: Newbury House Publisher; 1987: 15-30.

18. Wong SH, Webb TD. Uncovering meaningful correlation between student academic performance and library material usage. Coll Res Libr. 2011;72.4:361-70.

19. Crede' M, Roch SG, Kieszczynka UM. Class attendance in college: a meta-analytic review of the relationship of class attendance with grades and student characteristics. Rev Educ Res. 2010;80:272-95.

20. Chan KC, Shum C, Wright DJ. Class attendance and student performance in principles of finance. Financ Pract Educ. 1997;7(2):58-65.

21. Kirby A, McElroy B. The effect of attendance on grade for first-year economics students in University College Cork. Econ Soc Rev 2003;34(3):311-26.

22. Dolton P, Marcenaro D, Navarro L. The effective use of student time: a stochastic frontier production function case study. Econ Educ Rev. 2003;22(6):547-60.

23. Rodgers JR. Encouraging tutorial attendance at university 
did not improve performance. Aust Econ Papers. 2002;41(3):255-66.

24. Gupta A, Saks NS. Exploring medical student decisions regarding attending live lectures and using recorded lectures. Med Teach. 2013;35:767-71

25. Martin SI, Way DP, Verbeck N, Nagel R, Davis JA, Vandre DD. The impact of lecture attendance and other variables on how medical students evaluate faculty in a preclinical program. Acad Med. 2013;88(7):972-7.

26. West C, Sadoski M. Do study strategies predict academic performance in medical school? Med Educ. 2011;45(7):696-703.

27. Salamonson Y, Everett B, Koch J, Wilson I, Davidson PM. Learning strategies of first year nursing and medical students: a comparative study. Int J Nurs Stud. 2009;46(12):1541-7.

28. Lacina JG. Preparing international students for a successful social experience in higher education. New Dir High Educ. 2002;117:21-8.

29. Ridley D. Puzzling experiences in higher education: critical moments for conversation. Stud High Educ. 2004;29(1):91-107.

Cite this article as: Walke YS, Samuel LJ, Bandodkar LV. A cross-sectional comparative study to determine the factors contributing to the academic performance of the high performers and low performers in 2nd year medical students. Int J Basic Clin Pharmacol 2015;4:1072-9. 


\section{APPENDIX I}

\section{Questionnaire}

A. Learning strategies

1. Do you have regular disciplined study schedule for academics?
(a) Yes
(b) No

2. Do you regularly prepare notes?

(a) Yes

(b) No

3. What is your minimum daily hours of study? (Specify in hours).

4. How many hours do you study during holidays? (Specify in hours).

5. What is your preferred mode of study?
(a) Self study
(b) Study with another friend
(c) Group study

6. How frequently do you revise the topics?
(a) Daily
(b) Weekly
(c) Monthly

7. Do you refer to previous question papers?
(a) Yes
(b) No

8. Do you do mind mapping of the topic?
(a) Yes
(b) No
(c) If yes do you do it for (i) few topics (ii) most of the topics

9. Do you use other techniques like mnemonics?
(a) Yes
(b) No

10. Do you take guidance from faculty/senior students?
(a) Yes
(b) No

11. How often do you refer books from the library?
(a) Never
(b) Sometimes
(c) Always

12. Do you learn from other sources like from:
(a) Patients
(b) Mistakes

13. How is your lecture/practical attendance?
(a) Regular
(b) Irregular

14. How would you rate your memory?
(a) Short-term memory: (i) Average (ii) Good (iii) Excellent
(b) Long-term memory: (i) Average (ii) Good (iii) Excellent

B. Resource management

1. What is your preferred time for studies?
(a) Early morning
(b) Evening
(c) Late at night

2. What are your time management techniques?
(a) In college
(b) At home
(c) While travelling 
3. How much time is spent on watching TV, internet, etc? (Specify in hours).

4. How much time is lost in travelling? (Specify in hours).

5. Do your family members support you in your studies?
(a) Yes
(b) No
(c) If yes give details about it

6. How much time do you spend on social function in a month? (Specify in hours).

7. Time devoted to religious activities in a week? (Specify in hours).

C. Motivation

1. Are you motivated to study?
(a) Yes
(b) No
(c) If yes what is your source of motivation? (i) Intrinsic motivation (ii) Extrinsic motivation

2. Do exam results motivate you to study better?
(a) Yes
(b) No

D. Dealing with non-academic problems

1. How many hours do you sleep during exams? (Specify in hours).

2. Do you have Language barrier?
(a) Yes
(b) No

3. Do you feel homesick studying away from home?
(a) Yes

(b) No

4. How do you overcome distractions from friend?

5. How do you handle stress? 